\title{
Open access digital tools' contribution for mapping and monitoring of biodiversity
}

Biodiversity constitutes a source of natural richness of life on Earth, including all the variety of living organisms. The United Nations Organization proclaimed the period between 2011 and 2020 as the International Decade of Biodiversity. Knowing that the majority of the existing information about species distribution is not promptly reachable, the adoption of Georeferencing tolls as a brace for mapping, managing and handling of the biodiversity stands out. The present essay aims to describe the development and implementation of the Digital Atlas of Herpetofauna from the state of Pernambuco, a new digital tool of open access, which integrates data about species, their natural histories and their spacial distribution. For its development, the Joomla!, version 1.5.26, was adopted as Content Management System and the MySQL as Database System, these were integrated to the Library System PROJ.4 in order to enable graphic projections. The result is the developed tool itself, applying the combination of geographic data stored by mapping based on web browser. This study presented advantages found in the use of open access digital tools for mapping and monitoring species, pointing that its use is a very effective way to aggregate and communicate information about biodiversity.

Keywords: Environmental Management; Georreferencing; Computer Science applied to Biodiversity; Conservation Biology.

\section{Contribuição de ferramentas digitais de acesso aberto para mapeamento e monitoramento da biodiversidade}

\begin{abstract}
A biodiversidade constitui uma fonte de riqueza natural da vida na Terra, incluindo toda a variedade de organismos vivos. A Organização das Nações Unidas proclamou o período entre 2011 e 2020 como a Década Internacional da Biodiversidade. Sabendo que a maior parte das informações existentes sobre a distribuição das espécies não são prontamente alcançáveis, destaca-se a adoção do Georreferenciamento como meio de mapeamento, manejo e manejo da biodiversidade. 0 presente ensaio tem como objetivo descrever o desenvolvimento e implementação do Atlas Digital da Herpetofauna do estado de Pernambuco, uma nova ferramenta digital de acesso aberto, que integra dados sobre as espécies, suas histórias naturais e sua distribuição espacial. Para o seu desenvolvimento foi adotado o Joomla!, versão 1.5.26, como Sistema de Gerenciamento de Conteúdo e o MySQL como Sistema de Banco de Dados, estes foram integrados ao Sistema de Bibliotecas PROJ.4 para possibilitar projeções gráficas. O resultado é a própria ferramenta desenvolvida, aplicando a combinação de dados geográficos armazenados por meio de mapeamento baseado em navegador da web. Este estudo apresentou vantagens encontradas na utilização de ferramentas digitais de acesso aberto para mapeamento e monitoramento de espécies, apontando que seu uso é uma forma bastante eficaz de agregar e comunicar informações sobre a biodiversidade.
\end{abstract}

Palavras-chave: Gestão Ambiental; Georreferenciamento; Ciência da Computação aplicada à Biodiversidade; Biologia de conservação.

Topic: Conservação da Biodiversidade

Reviewed anonymously in the process of blind peer
Received: 02/03/2021

Approved: 24/05/2021
Wellington Buarque de Souza (iD

Universidade Federal Rural de Pernambuco, Brasil

http://lattes.cnpq.br/3411233450610564

http://orcid.org/0000-0001-9752-4377

biowbuarque@yahoo.de

Geraldo Jorge Barbosa de Moura (ic)

Universidade Federal Rural de Pernambuco, Brasil

http://lattes.cnpq.br/1348666346504103

http://orcid.org/0000-0001-7241-7524

geraldojbm@gmail.com

\section{Heiko Max Brunken (iD}

University of Applied Sciences, Alemanha

http://lattes.cnpq.br/0602560360206334

http://orcid.org/0000-0002-3745-5629

heiko.brunken@hs-bremen.de

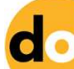

DOI: 10.6008/CBPC2318-2881.2021.002.0004
Valdir Paulo Ferreira Filho (iD

Universidade Federal Rural de Pernambuco, Brasil

http://lattes.cnpq.br/3254150345976475

http://orcid.org/0000-0002-3441-0716

valdir.paulo@gmail.com

Anne Drielly dos Santos Barbosa

Universidade Federal Rural de Pernambuco, Brasil

http://lattes.cnpq.br/4259213982503809

annedriellybsilva@gmail.com
Referencing this:

SOUZA, W. B.; MOURA, G. J. B.; BRUNKEN, H.; FERREIRA FILHO, V. P.; BARBOSA, A. D. S.. Open access digital tools' contribution for mapping and monitoring of biodiversity. Nature and Conservation, v.14, n.2 p.33-45, 2021. DOI: http://doi.org/10.6008/CBPC23182881.2021.002.0004 


\section{INTRODUCTION}

Biodiversity constitutes a source of natural richness of life on Earth, including all the variety of living organisms, and provides the basis for maintenance of all life forms (WWF, 2020). Biodiversity can be understood, in simplified form, as a set of ecosystems which allows the maintenance of the variety and genetic variability of living beings species to ensure their permanence in the environment (PRIMACK, 2001). However, this set of ecosystems for centuries - and more sharply in recent decades - has been dramatically affected by numerous human interventions, in a negative way (JENKINS, 2003), in such a way that several species have disappeared rapidly on the entire world, which has led biological diversity to a constant and considerable decrease, both in quantitative and qualitative (JANZEN, 1986).

Due to biodiversity importance, a considerable number of measures for its mapping, conservation and sustainable use are being developed in the world. In Brazil, an example of such measures is the Research Program on Biodiversity (PPBio, in portuguese), created in 2004 in order to intensify studies on biodiversity. Alongside these programs, and due to the large volume of data that has been generated worldwide about the subject, the place that computer science has occupied on this field can be highlighted, providing a significant contribution on development of platforms, softwares, and computational frameworks that are presented as important tools related to the order and appropriate data storage, providing access to information about the biology of the species (RODRIGUES et al., 2010).

Knowledge of the biological diversity is still incipient and disaggregated. What has been found is that the big majority of the existing information about the species distribution is not promptly reachable for the scientists and public yet. According to Jetz et al. (2012), there is a huge amount of data in traditional libraries (paper) or digital databases not integrated with each other. When well-documented, records of observations, just like those generated by fauna and flora surveys and environmental impact studies, may also represent a valuable source of data (CANHOS, 2003).

In this line of thought, the efforts to provide an infrastructure based on Web environment become important, they seek to bring together the results of data from various researchers, enabling integration of different kind of information about species, with tools that increase monitoring and biodiversity conservation.

Another aspect to be considered is the adoption of georeferencing tools as support for monitoring, management and biodiversity management. There are several authors who have pointed to the use of Geographic Information Systems (GIS) for this purpose. Ferreira et al. (2008), in his studies about the evolution and state of art remote sensoring, mentioned several applications that have been made on the systematic survey of Brazilian vegetation, which points to the importance of the adoption of GIS systems for biodiversity mapping. Geographical coordinates of the place of collection of specimens deposited in biological collections are also essential to understand the geographical distribution of species and support biodiversity conservation (WILLIAMS et al., 1997; BOWKER, 2000; JETZ et al., 2012). In this sense, for more than one decade, it has been consolidated the recognition of the importance of using new technologies for 
storing, sharing and improvement of information about biodiversity (BISBY, 2000; EDWARDS et al., 2000; WILSON et al., 2003; GURALNICK et al., 2009; JETZ et al., 2012).

Based on this principle of compiling data for insertion into a platform and subsequent organization and provision of access, is that biologists and scientists of Information from University of Applied Science in Bremen (HSB) have developed a new framework, which can be accessed freely and free of taxes, featured as an open access tool, which aimed to bring together and integrate extensive data on different species and their distribution in different biological systems. The project was called Digital Atlas of Biodiversity (Digitale Biodiversitätsatlanten, original term, in German) (BRUNKEN et al., 2006).

Continuing the Fish Digital Atlas of Germany and Austria, first work of this project, a partnership has began, through an exchange agreement, between the University of Applied Sciences in Bremen and the Federal Rural University of Pernambuco (UFRPE), aiming the construction of two more Atlas as part and extension of Biodiversity Digital Atlas Project, one of those held in collaboration with the Department of Fisheries and Aquaculture UFRPE - the Fish Digital Atlas of Pernambuco, and the other one with the collaboration of the Herpetological Studies Laboratory and the Department of Paleoherpetology UFRPE Biology Herpetofauna Atlas of the State of Pernambuco, which was made available ad experimentum in 2012.

Given the contribution that digital tools can provide for the mapping of biodiversity, the present essay aims: to describe the construction, implementation and importance of the Herpetofauna Atlas of State of Pernambuco, as one of the tools developed by the project 'Biodiversity Digital Atlas', for conservation purposes; and perform a literature review on digital tools of free access with applicability in the biological sciences, presenting a list of tools available on the web environment. The referred Atlas was developed in order to map the existing Herpetofauna in Pernambuco, pointing the studies that have been or are being carried out with these taxa, which include surveys of several faunal data as: areas of occurrence, case registration and determination of ecological factors. The mapping of these data, in its turn, offers us an important diagnosis about the species conservation status of herpetofauna that occur throughout the territory of the State of Pernambuco (including Fernando de Noronha Archipelago).

Presented as a new digital tool, the Herpetofauna Atlas of Pernambuco is available as an open access tool and we would like to propose it as a basic framework, that can contribute to the study and mapping of species that have occurred in that State.

\section{MATERIALS AND METHODS}

Initially, a literature review related to digital tools applicable to biological and environmental sciences was carried out, providing support for mapping, monitoring and biodiversity conservation. Among the publications that have been gathered, we focused in the works and studies that refer to free access tools, which here call for open access tools.

Parallel to this review, was conducted, in the network environment, a search for other digital tools that present, as assignment, the availability of biological data. In our study, we consider only the tools that were developed in the Americas and that offer georeferenced species service by viewing maps with 
information about the geographical distribution of species. The second step of the methodology refers to the implementation and development phase of the Digital Atlas, from the chosen content management system, and has been accomplished by the choice and incorporation of necessary components for the inclusion of the information in the database and later access by multi-user.

\section{Requirements for the development of a Framework}

The project 'Biodiversity Digital Atlas' was developed aiming to provide multiple scientific information of the various species under study in a single system, putting them to the online provision, by offering free access, and compliance with the legal provisions of copyright. Therefore, it was required that the integration of the other scientific informations was coordinated in a careful way by experts of biology.

\section{Criteria for implementing the Atlas}

Since most part of the Fish Digital Atlas data from Germany and Austria (BRUNKEN et al., 2012) was inserted with the support of the Content Management System (CMS) Joomla!, in its version 1.5.26, a CMS of an easy use, the same system was adopted for the implementation of the Brazilian atlas by UFRPE. In both cases, the expansion of Joomla!, Management System aggregating components for managing data on different species was required. So, the needs of the various groups of users, who have access to our framework, were taken into consideration.

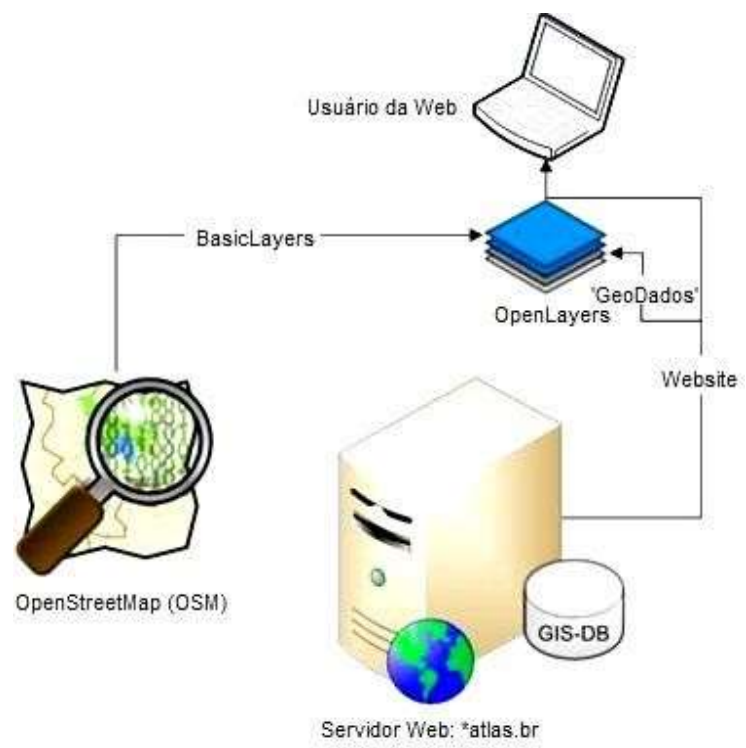

Figure 1: The current architecture framework model for biodiversity maps, where the Web user accesses, on the Frontend, information that was previously entered in Backend. The *atlas.br refers to the specific name of the taxonomic class of its elaborate Atlas (BRUNKEN et al., 2011).

The CMS Joomla! provides support for creation of interfaces to the various user groups from a distinction between the early components (Backend) and end (frontend) of the assembly process. This concept was adopted within the established framework (Figure 1), to specify different ways to access the content: 1 . Users who access the information offered by the system have unlimited access to the Frontend; 2. Users who contribute to the continuous development of the system, which, after prior registration, access 
an additional functionality in the Frontend; 3. Biology professionals responsible for the generation of data and that examine the quality of the entered information, with administrative access to parts of the Frontand Backend; 4. Joomla! managers, with unlimited access to Front- and Backend.

Due to the current architecture of the system Joomla! MySQL was chosen as the database management system (DBMS) for the administration of all data, considering its easy portability to different operating systems. It was necessary to integrate to this system one additional functionality for performing geographic projections, we opted for PROJ.4, considered one of the most important GIS area libraries (BRUNKEN et al., 2011), which was integrated into the Joomla! through an own plugin developed for this purpose. PROJ.4 was adopted because it is a JavaScript library that converts point coordinates from one coordinate system to another, including data conversion (GENZEL, 2011). By enabling these conversions in the browser, was allowed to spatial data stored in different projections to be combined into mapping applications based on a web browser. Administrative combinations, on the framework, of the inception of distribution data with map data from various sources have been inserted with the help of Web-GIS Open Layers Library and followed the protocol adopted by Genzel (2011).

\section{Framework Development}

The same framework that was the basis for the implementation of the Fish Atlas from Germany and Austria, developed in HSB (BRUNKEN et al., 2011), was also adopted for the development of biodiversity maps for other species. Thus, the Herpetofauna Atlas of the State of Pernambuco was developed in cooperation between the two higher education institutions (HSB and UFRPE) and has been applied and tested on a research project that is in continuous improvement. The inclusion of the information in System Joomla! followed the standard protocols provided by the SGC itself and was carried out by a team of undergraduates of Biological Sciences in UFRPE who received specific training for administration of this system. The information was inserted by the access to the system Backend by 'administrative area of the site', in a separate component developed for this framework, which was called Biodiversity Atlas (Figure 2). The scientific names of herpetological species that were included in the Biodiversity Atlas were updated according to the Brazilian Herpetological Society. The species conservation status followed the IUCN official list at the time of implementation of the Atlas. As updates followed, the current status is in accordance with the latest IUCN list.

A Frontend segment of the maps currently under construction is shown in Figure 3. In this example, the studied specie is the Tropidurus hispidus (squamate, Tropiduridae); Atlas provides, upon selection of the species by their scientific name, information about their biology, as well as a map with notes about their location. With a click on one of these dots, additional informations are presented about the place of registration, the date the specimen was observed, the information author and a short comment about the conditions of observation or collection when provided by the collector. Figure 4 shows the interactive input of informations about the species habitat. The exact location can be identified by the numerical coordinates or by clicking on the map (GENZEL, 2011; BRUNKEN et al., 2011). After the administrator confirmation, the 
signs of the coordinates are incorporated into the system along with the information about the date of collection and the origin of data.

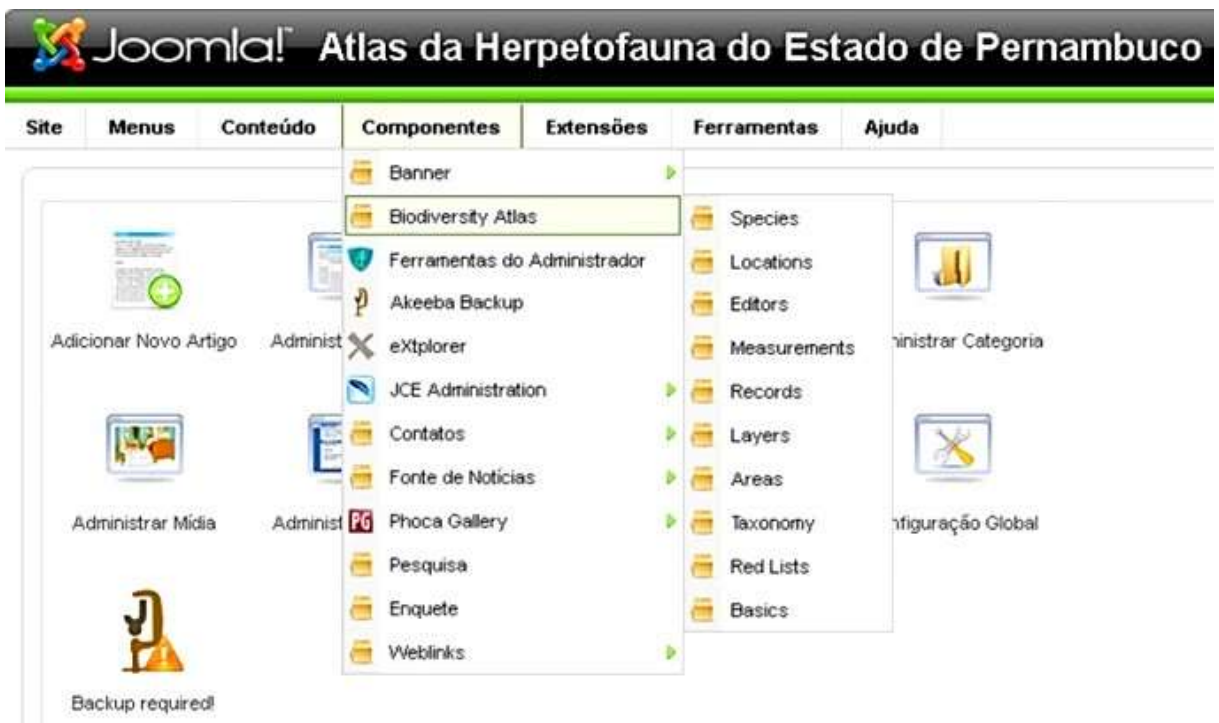

Figure 2: Biodiversity Atlas component was incorporated into the CMS Joomla! as the main tool of the framework developed for the integration and management of information of the Brazilian species.

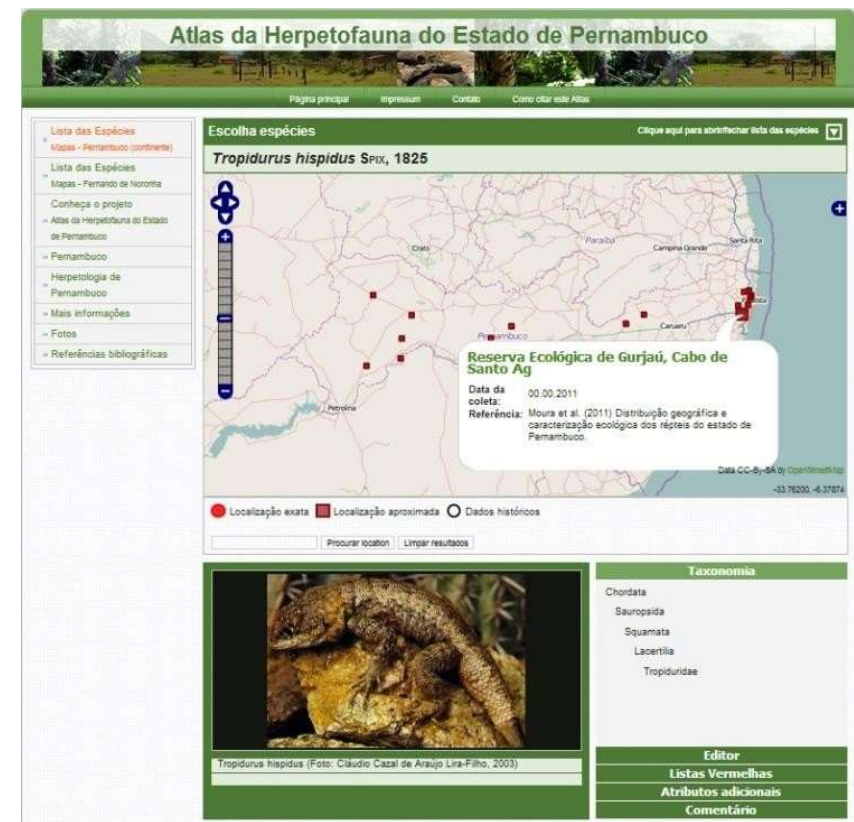

Figure 3: Frontend. Example: Herpetofauna Atlas of the State of Pernambuco. Information view about the referred species.

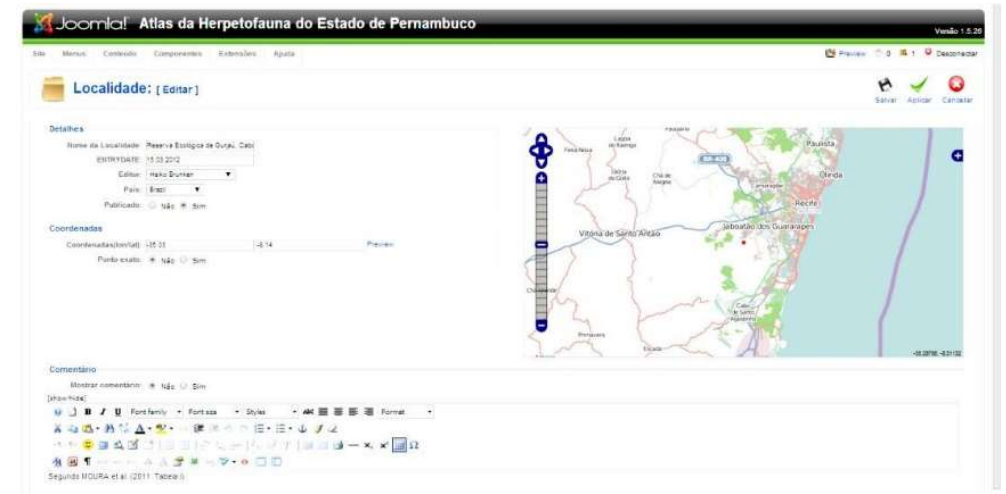

Figure 4: Backend. Example: Herpetofauna Atlas of the State of Pernambuco. Inception of location data in the Biodiversity Atlas component. 


\section{RESULTS}

The developed tool

As a result of the work, we have the developed tool itself and offered in the Web environment, providing information for free - open access - one of the main advantages of our framework for all users. The Atlas became operational in 2012, ad experimentum. Since then, it has been tested in terms of carrying capacity of its database, with the constant updating of its information and the continuous addition of new data, aiming to expand increasingly the contribution that our tool can offer. More than 11,700 accesses, have been registered, just by users-visitors. As an additional contribution to monitoring and decision-making, regarding the biodiversity conservation in the state of Pernambuco, there are available, in the Atlas, additional biogeographic information about Pernambuco, namely: climate, ecosystems and protected areas.

All species reported for the State of Pernambuco were registered and are available for consultation on the Digital Atlas database, more precisely on the Biodiversity Atlas component, and is worth mention that the Herpetology Art State, in Pernambuco, presented on the work 'Herpetofauna of Pernambuco' (MOURA et al., 2011a) has brought a majority contribution to the provision of data for all 189 herpetofauna species that have been reported in Pernambuco, in particular the data which are presented in Chapters 2 and 14 by Moura et al. (2011a), which displays the list of amphibians and reptiles occurrences, respectively, on Pernambuco. As a Content Management System, Joomla!, currently features, as 'use rights' for those who access the Atlas of Herpetofauna the State of Pernambuco, the following functional offerings, according to the different levels of access (GENZEL, 2011): a) as a visitor, you can view the maps available with approximate locations, access inserted free comments, species information, images and photos; b) as registered user, it is possible to view the maps available with specific locations, to insert locations, and also access user's own location data; c) as content manager, you can access the backend, make sure locations, manage data (add, change, delete), enter general comments and information about the species, manage map representations (add, change, delete); d) as a content administrator, you can manage the Joomla CMS!.

\section{Other tools in use}

Our study pointed to the need of important initiatives in the area of information systems about biodiversity. These initiatives have been presented as network tools that can gather and provide a good amount of data about taxa and species. It is presented, below, the tools included on our study, they are shown in an illustrative list, and that fall within the pre-established criteria, and are focused on projects that link the specific data management in an innovative way, from computational tools that can be applied to Conservation Sciences (Table 1).

The AmphibiaWeb is presented as a tool that provides an integrated Web service, developed by the University of California, USA, which provides multiple sources about amphibians in a global level, with continuous updates about the families taxonomy. It provides a stable reference system in a way to sort the taxonomic information and arrange them as support for other databases (e.g. IUCN). Currently presents the 
record of 2,370 species from all around the world, including current names, sound files, photos, videos, combined literature references with data trigger points, along with maps of specialized range with availability of georeferenced information. Its information can be found associated with IUCN Red List and CITES. The Encyclopedia of Life is a tool that is available from Harvard University, USA, in 2008, although the idea for the creation of this online database of species had already been developed years earlier (WILSON, 2003). It is currently held by sixteen different institutions, and it aims to provide a global access to knowledge about life on Earth; in view of this, it is showing an increasing expansion in order to become a global community of developers seeking to offer services to multi-users, both the community at large, as well as students and professionals from around the world scientists. For managing of its information was created a database - the TraitBank $^{\mathrm{TM}}$ - which currently has more than three million records on 272,720 different taxa obtained from over 29 data sources.

Table 1: Main digital tools developed by research institutions and Government in the Americas, highlighting some features presented by each. $\left({ }^{*}\right)$ Number of languages available in the GSC Backend.

\begin{tabular}{|c|c|c|c|c|c|c|}
\hline TOOL & Origin Country & $\begin{array}{l}\text { Numbers of } \\
\text { available } \\
\text { languages }\end{array}$ & $\begin{array}{l}\text { Species } \\
\text { Registration } \\
\text { Points }\end{array}$ & Species Biology & $\begin{array}{l}\text { Features } \\
\text { Red Lists } \\
\text { (IUCN or } \\
\text { others) }\end{array}$ & Servers Maps \\
\hline Amphibia Web & USA & 1 & Yes & Yes & Yes & Berkeley Mapper \\
\hline $\begin{array}{l}\text { Encyclopedia of } \\
\text { Life (EOL) }\end{array}$ & USA & 19 & Yes & Yes & Yes & Open Street Map \\
\hline SpeciesLink / CRIA & Brazil & 2 & Yes & Yes & Yes & Species Mapper \\
\hline CNCFLora & Brazil & 1 & Yes & Yes & Yes & Own Maps \\
\hline $\begin{array}{l}\text { Atlas de Peixes de } \\
\text { Pernambuco }\end{array}$ & Brazil & $1\left(3^{*}\right)$ & Yes & Yes & Yes & Open Street Map \\
\hline $\begin{array}{l}\text { Atlas da Herpetof. } \\
\text { de Pernambuco }\end{array}$ & Brazil & $1\left(3^{*}\right)$ & Yes & Yes & Yes & Open Street Map \\
\hline
\end{tabular}

Considering Brazil, we also have some specific search and providing information on species tools. Among these, we can mention the SpeciesLink Network from the Foundation for Research of the State of São Paulo, available since 2002 by the Environmental Information Reference Center (CRIA), whose mission is to disseminate scientific and technological knowledge, promote education and training of citizenship. SpeciesLink is a distributed information system that integrates in real-time primary data of scientific collections. The system was developed with the support of Brazilian and international research institutions.

The SpeciesLink Network, as it is a free access tool, is designed to promote free and open access to data, information and tools available to any individual or group in order to encourage public use of scientific information. It presents, until this date, 6.400 .00 online records, and 4.98 million of which, are georeferenced records (77.7\% of total registrations).

Another tool that has contributed to the mapping of the national biodiversity is the SI Plant Conservation National Center (CNCFlora), managed by the Institute of Botanical Garden of Research of Rio de Janeiro (IPJBRJ). This Information System has as one of its objectives to coordinate the list of species of Brazilian Flora, in addition to the official list of species of flora threatened of extinction. To do this, the system has developed and now manage a database on plant biodiversity, developing a national strategy for the conservation of endangered species. The IPJBRJ stands out for having one of the largest bases of flora data, 
with 450,000 records online approximately (SILVA et al., 2010). Among the components that integrate its database, a taxonomic scope can be found, which allows the creation of hierarchical vocabularies from the taxonomy information of the species recorded.

Other tools have been found in our systematic search, which are developed by various institutions in the vast territory of the Americas, but they don't provide georeferencing data for species that are presented in their lists and databases. One of these, sets the Amphibia Species of the World (FROST, 2020), developed by the American Natural History Museum, in USA, which has the mission to provide a systemic and updated report of the current taxonomic organization of the amphibian orders and families. It also displays the consulted references, however, when talking about geographical distribution of species, it is limited to a brief description without visualization by maps.

It is worth to talk about the important role of the Global System of Biodiversity Information Facility (GBIF), in this case a portal that assembles the data, which collects and makes available records of museums around the world and whose searches can be made about a particular country, taxonomic level or type of name (GBIF, 2020). This free access portal provides a lot of visualization tools and Application Programming Interfaces (APIs) to promote data exchange. Although it does not meet the criteria of our survey, it's necessary to mention it, given the essential support that it offers to the open-access frameworks developed in the Americas.

Finally, it is worth to consider the importance that 'The Reptile Database' tool has in the area of Herpetology, providing important information about more than 9,800 species worldwide, including data georeferencing (UETZ et al., 2020); and the IUCN Red List, although both are not tools developed in the Americas. The last one has established itself as a huge portal that should be mentioned as a key tool that has served as support for several others. Through its evaluation of taxa, that are based on an extensive network of experts, it has become a key that aggregates and disseminates maps of specialized areas, and have your information to numerous databases, for example, for all databases that were mentioned in the scope of these results.

\section{DISCUSSION}

After the considerations of the results of the implementation of Herpetofauna Atlas of the State of Pernambuco, it is time to make an approach about the advantages and disadvantages of the chosen parameters for the realization of this project, and about the different services offered by the others tools mentioned.

One of the concerns existing at the start of recording data in the Joomla system components! was the carrying capacity of this SGC. It has been found along the insertion of new records that the carrying capacity was highly extensible and has responded effectively to the demand for system access and information, is the frontend to the backend.

In comparison to other SKMS, Joomla! enables simple user handling. Due to a strict separation between management and visualization on frontend and backend, functions can be clearly attributed and 
differentiated. On frontend is displayed the Website and is enabled to the user a limited number of possibilities of interaction, while on backend the view, as the website content, can be conceived and designed. Since the frontend and the backend are on the same Web server, no other tool is needed to manage content. The great advantage of adopting Joomla! as our work GSC is that it dispenses data programming and, therefore, can be managed by professionals of any field, which certainly does not preclude professionals integration of Information Sciences at the project execution team.

It is essential that the processing of data and the addition of new records be supervised by professionals of Biological and Environmental Sciences, in order to avoid errors of occurrence records and subsequent difficulties when identifying the data on the species, which was mentioned by Silva et al. (2019) in their work.

Overall, the adoption of the use of more than one language did not present any cost because Joomla! presents common components for the use in various languages, which in the context of computational frameworks are used for a lot of applications. Genzel (2011) used this framework as a standard on his works, showing to be feasible the adoption and integration of other languages to the system, as the demand of use from multi-user.

We can also infer that the Herpetofauna Digital Atlas of Pernambuco can offer a significant contribution to regional mapping of Herpetofauna's species, by providing, on the Web environment, information about the biology and spatial distribution of these species; This information, when aggregated with other informations from other sources (e.g. other databases), establishing external links to other sites and portals through associated links, may expand the range of the provision of services that the framework can provide . According Jetz et al. (2012), these external links to multiple databases and their interactions are initiatives that inspire the idea of a true integrated spatial biodiversity infrastructure, in the same context of initiatives based on service that the network can offer.

Since Joomla! is available under the GNU (General Public License), is considered as a free source system (Open Source) and presents accessible free of charge, freely modifiable and usable without restriction. However, according Genzel (2011), this opening provides no guarantee because it is assumed that there is no contractual relationship of use. Just by be presented as an Open Source tool, there is a community that cares about the development and evolution of the system, and a central team that manages and monitors these developments. In addition to the Joomla! developers, there are still several other developers, who continuously research the implementation of extensions for Joomla!. This will result in many possibilities of application for this system, according Genzel (2011).

There is still the possibility of the tool to offer interactivity to its users, such as an utility that gives the tool the provider status of some key services, in which case they become, according to Castro (2010), a support for the user to 'improve' the quality of data and collections that will be recorded.

Consider the availability of data about the biology of the species, added to the data on their ecology and reproduction, when associated with the species registration sites, makes the tool offer more presentable. In this sense, according to Williams et al. (1997), when the geographic location is included with 
precise coordinates of points, it brings important elements to guide management plans and conservation of species.

As an example, SpeciesLink Network, by CRIA, has this differential, providing some applications that support species data management; such tools include information about geographic coordinates, ecological niche modeling techniques and generation of potential distribution maps of species. According to Lange et al. (2013), these applications make that the developed framework have considerable emphasis, which leads to the optimization of information management about the species that will later be recorded by users.

Considering that on the mentioned tools was found a larger number of accesses to georeferenced species data, which was presented in percentage terms in the case of SpeciesLink Network, we can confirm the importance of the application of Geographic Information Systems for studies on species distribution.

Longhi et al. (2005) mentioned that the GIS, combined with remote sensing and the use of the database, are of fundamental importance for the study and management of natural resources and biodiversity, allowing better monitoring, evaluation and management information.

Koga et al. (2011) on their studies, present a proposal to integrate sensing systems in the study of environmental factors and their impacts on biodiversity, developing a computational framework that allows researchers in biodiversity combine queries to data collection with data networks sensors. The work assumes that there is data collections that are kept and made available on the Web by several groups of researchers.

In all the analyzed tools is important to remember the importance of being operated by professionals in their respective fields of knowledge. The quality of information that is entered in biodiversity Sls is very important, given the accuracy of the information are directly linked, in some cases, the decision-making on conservation projects. The quality of information that is entered in biodiversity SIs is very important, given the accuracy of the information are directly linked, in some cases, the decision- making on conservation projects. Other studies also mention the need to properly prepare the professionals who deal with the quality of data available (BISBY, 2000; EDWARD et al., 2000; GURALNICK et al., 2009; SILVA et al., 2010.).

Finally, it is possible to see this cooperation in all analyzed tools. This is found by checking the integration of professionals of Information Sciences work with the professionals of Biological and Conservation Sciences; this is confirmed by the interdisciplinary model adopted in the implementation of each project. Corroborating the need for such cooperation, Jetz et al. (2012) report such initiatives as an integration of data from various areas of knowledge, in order to optimize the services that are offered to the efforts for biodiversity conservation.

\section{CONCLUSIONS}

In the current context, where much has been said about Economics of Ecosystems and costs of biodiversity conservation, the adoption of new open access tools has proved a viable and effective means to share knowledge, aiming to add efforts on the communication of information on biodiversity.

Taking into consideration the growing demand of expanding our framework, everyone involved in the project are aware of the limitations of the developed tool and, at the same time, it is understood that 
there is still much to be done to implement improvements on the its services, mainly when talking about the questions in the context of use and application of GIS. In addition, it has been studied the development of tools for access via Android ${ }^{\mathrm{TM}}$ or iOS ${ }^{\mathrm{TM}}$ System.

It is expected that the Herpetofauna Atlas of the state of Pernambuco, together with the other tools of the Project 'Biodiversity Digital Atlas', include the provision of such applications among its services, which has been studied by Sciences Information team of professionals involved in this project.

It is considered the great potential that the Herpetofauna Atlas of Pernambuco has. This one added to other Atlas that were developed and others that were not developed yet, and that integrate the Biodiversity Atlas network, will present themselves as tools that will contribute significantly for the construction of Red Lists of endangered species, both of Pernambuco and the Northeast.

It is important to communicate that the Herpetofauna Atlas of Pernambuco is part of the project 'Digital Atlas of Biodiversity', which was chosen in Germany, in November 2013 as "Official Project of Biodiversity UN Decade 2011-2020". This award is given to the projects that are making efforts for the conservation of biodiversity.

ACKNOWLEDGEMENTS: The authors thank Tiago Salvador and Ana Carolina Miranda, for the Translation and English corrections, the Team from LEHP - UFRPE and the technical Team from the University of Applied Science in Bremen, Germany, for the support on the Information Technology.

\section{REFERENCES}

BISBY, F. A.. The Quiet Revolution: Biodiversity Informatics and the Internet. Science, v.289, n.5488, p.2309-2312, 2000 DOI: https://doi.org/10.1126/science.289.5488.2309

BOWKER, G. C.. Mapping biodiversity. Int. J. Geographical Information Science, v.14, n.8, p739-754, 2000. DOI: https://doi.org/10.1080/136588100750022769

BRUNKEN, H.; GENZEL, C. H.; VATTERROTT, H. R.; WINKLER, M.. Digitale Biodiversitätsatlanten: Tools zur Unterstützung regionaler und internationaler Expertennetzwerke für die Erfassung und Bewertung biologischer Diversität. In: Umweltbundesamt (Hrsg.), Umweltinformationssysteme. Frühwarn- und Informationssysteme für den Hochwasserschutz. Umweltbundesamt, 2012. p.161-169,

BRUNKEN, H.; BRUNSCHÖN, C.. Digitaler Fischartenatlas von Deutschland: eine Projektbeschreibung. Verhandlungen der Gesellschaft für Ichthyologie, n.5, p.27-34, 2006.

CANHOS, V. P.. Informática para biodiversidade: padrões, protocolos e ferramentas. Ciência e Cultura, v.55, n.2, p.4547, 2003. ISSN 0009-6725.

CASTRO, S. C.; TAVARES, D. L. M.; FREITAS, C. M. D. S.. Integrando Visualização e Análise de Dados em Sistemas de Gerenciamento de Dados de Biodiversidade. In: eScience - IV Science Workshop. In: CONGRESSO DA SOCIEDADE BRASILEIRA DE COMPUTAÇÃO, 30. Anais. Belo Horizonte, 2010. p.177-184.
EDWARDS, J. L.; LANE, M. A.; NIELSEN, E. S.. Interoperability of Biodiversity Databases: Biodiversity Information on Every Desktop. Science. v.289, n.5488, p.2312-2314, 2000. DOI: https://doi.org/10.1126/science.289.5488.2312

FERREIRA L. G.; FERREIRA, N. C.; FERREIRA, M. E. Sensoriamento remoto da vegetação: evolução e estado-daarte. Acta Scientiarum. Biological Sciences, Maringá, v.30, n.4, p.379-390, 2008. DOI: https://doi.org/10.4025/actascibiolsci.v30i4.5868

FROST, D. R.. Amphibian Species of the World: an Online Reference. Versão 6.0. Electronic Database. New York, USA: American Museum of Natural History, 2020.

GBIF. Global Biodiversity Information Facility. Versão 1.0. 2020. Copenhagen, Dinamarca, 2020.

GENZEL, C. H.. Web GIS Erweiterung des CMS Joomla! im Kontext der Biodiversität. Bachelor-Arbeit (Bachelor on Internationaler Studiengang Medieninformatik) - Facultät für Elektrotechnik und Informatik, Hochschule Bremen, 2011.

GIL, F. B.. Serviço Web para Anotação de Dados Geográficos Vetoriais e sua Aplicação em Sistemas de Informação de Biodiversidade. Dissertação (Mestrado em Ciência da Computação) - Universidade Estadual de Campinas, Campinas, 2009.

GURALNICK, R.; HILL, A.. Biodiversity informatics: automated 
approaches for documenting global biodiversity patterns and processes. Bioinformatics, v.25, n.4, p.421-428, 2009. DOI: https://doi.org/10.1093/bioinformatics/btn659

JANZEN, D. H.. The eternal external threat. In: SOULÉ, M.. Conservation Biology: The Science of Scarcity and Diversity. Sunderland: Sinauer Associates, 1986. p.330-444.

JENKINS, M.. Prospects for biodiversity. Science, v.302, n.5648, p.1175-1177, 2003. DOI:

https://doi.org/10.1126/science.1088666

JETZ, W.; McPHERSON, J.; GURALNICK, R. P.. Integrating biodiversity distribution knowledge: toward a global map of life. Trends in Ecology and Evolution. v.27, n.3, p.151-158, 2012. DOI: https://doi.org/10.1016/j.tree.2011.09.007

KOGA, I.; MEDEIROS, C. M. B.. Gerenciamento de dados de sensores para Sistemas de Informação de Biodiversidade. In WORKSHOP DE TESES, DISSERTAÇÕES E TRABALHOS DE INICIAÇÃO CIENTÍFICA EM ANDAMENTO DO INSTITUTO DE COMPUTAÇÃO DA UNICAMP, 6. Anais. Campinas, 2011. p.18-20.

LANGE, D.. Sistemas de Informação em Biodiversidade e a formulação de políticas públicas na era digital. Tese (Doutorado em Política Científica e Tecnológica) Universidade Estadual de Campinas, Campinas, 2013.

LONGHI, A. L. B.; MENESES, P. R.. Uso de Técnicas de Geoprocessamento e Sensoriamento Remoto para o Zoneamento de Florestas Nacionais. In: SIMPÓSIO BRASILEIRO DE SENSORIAMENTO REMOTO, 12. Anais. Goiânia: INPE, 2005. p.2245-2250.

MOURA, G. B. M.; SANTOS, E. M.; OLIVEIRA, M. A. B.; CABRAL, M. C. C.. Herpetofauna no Estado de Pernambuco. Brasília: IBAMA, 2011.

NASCIMENTO, M. C.; SILVA, M. P.; JÚNIOR, S. A. M. G.. Geoprocessamento aplicado a análise dos impactos ambientais na cobertura vegetal da Área de Proteção Ambiental de Santa Rita, Alagoas-Brasil. In: SIMPÓSIO BRASILEIRO DE SENSORIAMENTO REMOTO, 14. Anais. Natal, 2009. p.4101-4108.

PNUMA. A Economia dos Ecossistemas e da Biodiversidade. Cambridge, 2008.

PRIMACK, R. B.; RODRIGUES, E.. Biologia da conservação. Londrina: Planta, 2001.
RODRIGUES, A. S. L.; PILGRIM, J. D.; LAMOREUX, J. F.; HOFFMANN, M.; BROOKS, T. M.. The value of the IUCN Red List for Conservation. Trends in Ecology and Evolution, Washington, v.20, n.20, p.1-6, 2005. DOI: https://doi.org/doi:10.1016/j.tree.2005.10.010

RODRIGUES, F. A.; RODRIGUES, E. S. C.; CORRÊA, P. L. P.; ROCHA, R. L. A.; SARAIVA, A. M.. Modelagem da Biodiversidade Utilizando Redes Neurais Artificiais. In: II Workshop de Computação Aplicada à Gestão do Meio Ambiente e Recursos Naturais. In: CONGRESSO DA SOCIEDADE BRASILEIRA DE COMPUTAÇÃO - COMPUTAÇÃO VERDE: DESAFIOS CIENTÍFICOS E TECNOLÓGICOS, 30. Anais. Belo Horizonte: PUCMinas, 2010. p.585-594.

SARDÁ-PALOMERA, F.; BROTONS, L.; VILLERO, D.; SIERDSEMA, H.; NEWSON. S. E.; JIGUET, F.. Mapping from heterogeneous biodiversity monitoring data source. Biodiversity Conservation, v.21, p.2927-2948, 2012. DOI: https://doi.org/10.1007/s10531-012-0347-6

SILVA, L. A. E.; BARROS, R. O.; DALCIN, E.; ZIMBRÃO, G.; SOUZA, J. M.. Abordagem Colaborativa para a Melhoria da Qualidade de Dados em Bases de Dados Botânicas. In: II Workshop de Computação Aplicada à Gestão do Meio Ambiente e Recursos Naturais. In: CONGRESSO DA SOCIEDADE BRASILEIRA DE COMPUTAÇÃO - COMPUTAÇÃO VERDE: DESAFIOS CIENTÍFICOS E TECNOLÓGICOS, 30. Anais. Belo Horizonte: PUCMinas, 2010. p.535-544.

SILVA, L. A. E.; OLIVEIRA, F. A.; RIBEIRO, R.; COSTA, L. F. S.; SOUZA, L. C. S.. Aplicação da Análise de Agrupamentos em Dados de Coleções Científicas Botânicas. Revista Expressão da Estácio, Rio de Janeiro, v.1, n.1, p.43-51, 2019.

UETZ, P.; FREED, P.; HOŠEK, J.. The Reptile Database. Czech Republic: The Reptile Database, 2020.

WILLIAMS, P. H.; GASTON, K. J.; HUMPHRIES, C. J.. Mapping biodiversity value worldwide: combining higher-taxon richness from different groups. Biological Sciences, United Kingdom, v.264, n.1378, p.141-148, 1997. DOI: https://doi.org/10.1098/rspb.1997.0021

WILSON, E. O.. The encyclopedia of life. Trends in Ecology and Evolution, Cambridge, v.18, n.2, p.77-80, 2003. DOI: https://doi.org/10.1016/S0169-5347(02)00040-X

WWF. World Wildlife Fund. $O$ que é Biodiversidade?. Brasília: World Wildlife Fund, 2020.

A CBPC - Companhia Brasileira de Produção Científica (CNPJ: 11.221.422/0001-03) detém os direitos materiais desta publicação. Os direitos referem-se à publicação do trabalho em qualquer parte do mundo, incluindo os direitos às renovações, expansões e disseminações da contribuição, bem como outros direitos subsidiários. Todos os trabalhos publicados eletronicamente poderão posteriormente ser publicados em coletâneas impressas sob coordenação da Sustenere Publishing, da Companhia Brasileira de Produção Científica e seus parceiros autorizados. Os (as) autores (as) preservam os direitos autorais, mas não têm permissão para a publicação da contribuição em outro meio, impresso ou digital, em português ou em tradução. 